\title{
Paweł Gancarczyk: Petrus Wilhelmi de Grudencz i muzyka Europy Środkowej $\mathrm{XV}$ wieku
}

Warszawa : Instytut Sztuki Polskiej Akademii Nauk, 2021, 327 s. ISBN 978-83-66519-23-7

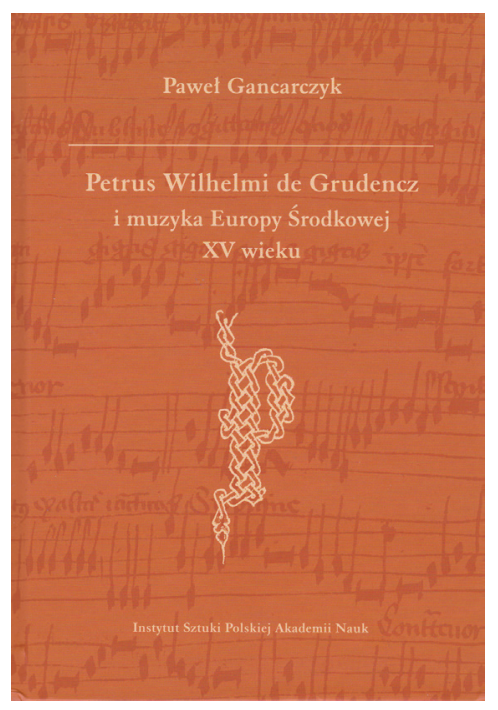

Názov málo známeho mesta Grudziądz (lat. Grudencz, nem. Graudenz) v severnej časti stredného Pol'ska, cez ktoré preteká rieka Visla, je súčastou mena hudobného skladatela obdobia stredoveku - Petrus Wilhelmi de Grudencz. V dejinách hudby bolo meno tohto skladatela neznáme až do roku 1975, ked' český muzikológ Jaromír Černý odhalil jeho identitu podla akrostichu $\mathrm{v}$ texte štvorhlasného moteta Pneuma eucaristiarum a následne na základe dôkladných výskumov zistil, že istý Petrus Wilhelmi de Grudencz - čiže „Peter, syn Wilhelma z Grudziądz“ študoval na krakovskej univerzite v rokoch 1418 až $1430 .{ }^{1}$ Objav hudby doteraz neznámeho skladatela je vždy velkou udalostou. V prípade „Wilhelmovho syna“, čiže skladatela s nemeckým menom - a navyše v období socializmu a vtedajšej straníckej ideologizácie pol'ských dejín - však vznikol problém, ako tohto skladatela zaradit do histórie Pol'ska. Podla mena totiž patril jednoznačne k nemeckej enkláve mesta Grudziądz, ktoré bolo počas života skladatela súčastou územia „nepriatelského“ Rádu nemeckých rytierov (križiakov). Kedže jeho význam pre dejiny pol'skej hudobnej kultúry bol otázny, vznikla potreba nájst' v jeho hudbe „polonizujúci“ prvok; a ten poskytlo jeho moteto Praesulis eminenciam obsahujúce modálny rytmus, ktorý kopíruje antické metrické stopy pripomínajúce rytmiku polských mazúrkových tancov. Dnes sú všetky takéto úvahy zabudnuté a prehodnotené. Profesionálny heuristický výskum viacerých európskych muzikológov je postavený na striktnej vedeckej interpretácii prameňov, akceptuje v hudbe Petra Wilhelma z Grudziądz spoločné európske idiómy a chápe polyfonickú hudbu tohto skladatela ako spoločné dedičstvo Pol'ska, Nemecka a Čiech, resp. ako „jeden z článkov rełaze spájajúcej kultúru neskorého stredoveku a raného novoveku na tomto území. 2 Na tejto myšlienke je postavená aj muzikologická monografia Pawła Gancarczyka, ktorá už v titule knihy dáva dôraz na európsky kontext riešenej problematiky.

Reprezentačná publikácia po všetkých stránkach (aj vizuálnej - tvrdá väzba, farebné fotografie, notové príklady) je vzorovou hudobnohistorickou monografiou venovanou

1 ČERNÝ, Jaromír: Petrus Wilhelmi de Grudencz - neznámý skladatel doby Dufayovy v českých pramenech. In: Hudební věda, roč. 12, 1975, č. 3, s. 195-235.

2 Memory and Tradition within the European Music Culture of the Late Middle Ages and the Early Modern Times. Dostupné na internete: <https://www.casopisharmonie.cz/serialy/pamet-a-tradice-v-evropske-hudebni-kulture-pozdniho-stredoveku-a-raneho-novoveku-5.html> 
jednej osobnosti. Autor analyzuje v samostatných kapitolách život skladatela, pramene jeho hudby, hudobné formy zastúpené v jeho tvorbe a vybrané hudobné diela. Úvodná stat' približuje peripetie okolo výskumu identifikácie skladatela a vyhodnocuje viacročné bádania v archívoch, ktoré osvetlili „cestu“, resp. „premenu" neznámeho autora menom „Petrus“ na renomovaného skladatela „Petra, syna Wilhelma z Grudziądz", ktorého hudba sa hrala v 15. storočí v mnohých mestách strednej Európy. Mimochodom, v knihe je uvedených devät rôznych foriem písania jeho mena $\mathrm{v}$ rukopisných dokumentoch z rokov 1418 - 1452 (napríklad Meister Petrus Wilhelmj, 1448). Záverečný prológ poukazuje na tie umelecké hodnoty jeho hudby, ktoré oslovili súčasných umelcov. Jeho hudba sa totiž od roku 1993 - ked' vyšla prvá pramenná kritická edícia jeho osemnástich skladieb - pravidelne predvádza na dnešných koncertných pódiách a stala sa už súčastou stredoeurópskeho hudobnokultúrneho dedičstva v Polsku i v okolitých krajinách. Vypočut si ju môžeme na viac než dvadsiatich CD nosičoch; prvé nahrávky vznikli v Polsku - súbory Bornus Consort a Ars Nova - neskôr sa jeho hudba dostala do repertoáru mnohých európskych súborov - Ars cameralis (ČR), Hilliard Ensemble (Vel'ká Británia), Stimmwerck (Nemecko), Vox Clamantis (Estónsko), Schola Gregoriana Pragensis (ČR), Ars cantus (Polsko), La Morra (Švajčiarsko). Viaceré CD nosiče s hudbou Petra z Grudziądz majú monografický charakter: Schola Gregoriana Pragensis (2005), Ars Cantus (2009), La Morra (2016), Bastarda (2017, Varšava). Navyše, nejde len o hudbu; jej recepcia $\mathrm{v}$ dnešných dňoch sa premietla aj do aktivít venovaných poznaniu historickej doby neskorého stredoveku, jej kultúry a regionálnych umeleckých tradícií v mieste pôvodu skladatela. Od roku 2015 sa dokonca na hudobnotopografickej mape polského mesta Grudziądz objavila alej s novým názvom Alej Piotra z Grudziądza. Nachádza sa na najmalebnejšom mieste na nábreží Visly, pod hradobnou štvrtou, ktorú ohraničujú niekol'koposchodové gotické mestské sýpky postavené z tehál. Tie priam evokujú esprit neskoro stredovekého mesta a lákajú na turisticky atraktívne prechádzky. Poliaci si vedia vážit svojich významných rodákov, aj hudobníkov. Nič to nemení na skutočnosti, že skladatel' bol typickým Stredoeurópanom, precestoval vel'kú čast' Európy vrátane Talianska; a tam - konkrétne v Ríme - sa archívne správy o jeho živote končia.

Petrus Wilhelmi de Grudencz (pol'sky Piotr z Grudziądza; nar. 1392, Grudziądz - zom. po 1452) bol nielen pol'ský stredoveký hudobný skladatel', ale aj básnik. V roku 1418 sa zapísal na univerzitu v Krakove, v roku 1425 tam dosiahol titul bakalár a v roku 1430 magister. Po odchode z Krakova pôsobil pravdepodobne vo Viedni a predpokladá sa, že neskôr sa zúčastnil koncilu v Bazileji, o čom svedčí jeho vlastná báseň Pontifices ecclesiarum. Archívne pramene dokázatel'ne dokumentujú, že v roku 1442 pôsobil ako kapelník (capellanus) na dvore cisára Fridricha III. a v roku 1448 bol istý čas vo Vroclave, kde sa uchádzal o post kanonika na dvore tamojšieho biskupa Petra Nováka. Posledný známy rok, ktorý je preukázatelne spätý s jeho životom, sa týka Talianska - v roku 1452 podnikol cestu do Ríma. Podla najnovších výskumov bol členom skupiny duchovných a hudobníkov v službách Fridricha III. počas jeho výpravy do Talianska. Bol teda účastníkom nielen korunovácie tohto nemeckého krála v Ríme, ale navštívil aj královský dvor v Neapole a dalšie mestá (Padova, Ferrara, Bologna, Florencia, Siena a zrejme i Benát$\mathrm{ky}){ }^{3}$ Svedčia o tom dokumenty $\mathrm{z}$ pápežského archívu, podla ktorých sobáš a korunováciu sprevádzala pápežská kapela, v ktorej bolo osemnást’ spevákov. Z nich jeden mal taliansky pôvod, ostatní franko-flámsky. Mená hudobníkov, ktorí sprevádzali Fridricha III., sa nezachovali kompletne; konkrétnejšie sa spomína len jeden šalmajista a jeden pozaunista. Zachovala sa však archívna správa, referujúca o kaplánoch (duchovných) a piatich kanto-

3 Fridrich III. (V.) Habsburský (1415 - 1493) - štajerský, korutánsky a kranský vojvoda (od r. 1435), rakúsky arcivojvoda (od r. 1457, ako Fridrich V.), nemecký král' (od r. 1440 ako Fridrich IV.) a rímsky cisár (od r. 1452 ako Fridrich III.). Cisárskej korunovácii v Ríme predchádzal sobáš s Eleonórou Portugalskou. 
roch, ktorí mali spolu k dispozícii tridsat koní ${ }^{4}$ Napriek tomu, že informácie o dalšom živote Petra z Grudziądz nemáme k dispozícii, autor knihy vyslovuje hypotézu, že neskôr zrejme mohol pôsobit aj v Čechách; totiž až v pätnástich českých mestách sa zachovali rukopisné pramene s jeho hudbou datované od 50. rokov 15. storočia (najviac v Prahe). Najnovšie výskumy, ktoré Paweł Gancarczyk sumarizuje v prvej kapitole Wókoł biografii, poskytujú detailný pohlad na archívne dokumenty vrátane revízie viacerých doterajších poznatkov o živote skladatela; napríklad dátum jeho narodenia upresňujú pápežské dokumenty na rok $1392 .{ }^{5}$

V druhej kapitole - Żrodła tworczości - nájdeme kompletný prehlad rukopisných prameňov obsahujúcich hudbu Petra z Grudziądz. Tie sú rozdelené na pramene $\mathrm{z}$ raného obdobia tvorby (1420 - 1460) a neskoršie pramene (1465 - 1726). Najstarší rukopisný prameň pochádza z Krakova (PL-Kj 2464) a obsahuje dve skladby z čias jeho štúdií: Presulis eminenciam (trojhlasná pieseň) a Pregrata era (pieseň k sv. Kataríne, zachoval sa jeden hlas z dvojhlasnej skladby). Kedže skladatel' vela cestoval a mal dobré kontakty s hudobníkmi v rôznych mestách Európy, rukopisy s jeho hudbou sa zachovali (často len fragmentárne) predovšetkým v strednej Európe (Krakov, Vroclav, Opava, Varšava, Ústí nad Orlicí, Vysoké Mýto, Třeboň, Sedlčany, Lipsko, Erfurt, Viedeň, Hradec Králové, Magdeburg, Nysa, etc.); najviac prameňov sa však zachovalo v Prahe, a to v jedenástich inštitúciách (knižnice, archívy, múzeá). Pri štúdiu jeho hudby majú osobitné miesto medzi európskymi prameňmi rukopisy Kódex Speciálník (Speciálník královéhradecký), Franusov kancionál, Chrudimský kancionál a Głogowský spevník vytvorený s najväčšou pravdepodobnostou v Sliezsku (Żagan, PL). Z nich Speciálník královéhradecký obsahuje široké spektrum renesančnej polyfonickej hudby európsky známych autorov, okrem Petra z Grudziądz sú to: Agricola, Bedyngham, Flemmik, Frye, Isaac, Josquin, Lannoy, Morton, Obrecht, Pullois, Touront, Weerbeke. Viaceré z českých prameňov - hlavne utrakvistické rukopisy - sú mladšieho datovania a poukazujú na dlhšiu, retrospektívnu tradíciu predvádzania hudby Petra z Grudziądz a dalšieho rozsiahleho renesančného repertoáru ešte aj v 16 . storočí. Autor knihy túto tradíciu skúma opät zo širšieho stredoeurópskeho kontextu a zdôrazňuje, že kultúra pestovania renesančnej polyfonickej hudby v prostredí utrakvistických literátskych bratstiev nebola čisto českou záležitostou, ale vzt̉ahovala sa na širšie európske teritórium.

Z hladiska územia dnešného Slovenska sú zaujímavé Spišské fragmenty (H-Bn lat. 534) pochádzajúce $\mathrm{z}$ väzby inkunábulu $\mathrm{z}$ knižnice kláštora dominikánov v Košiciach (datované na základe vodoznaku na roky 1437 - 1440). Obsahujú jedno moteto Petra z Grudziądz Presulem ephebeatum a tiež text jeho piesne Chrystus zmartwychwstal v štyroch jazykoch: pol'skom, českom, nemeckom a madarskom. Paweł Gancarczyk však poukazuje na to, že priame dôkazy o spišskej proveniencii rukopisu neexistujú. Z primárnych dôkazov o pestovaní renesančnej polyfónie $\mathrm{v}$ multikultúrnom, viacjazyčnom prostredí Spiša uvádza len jediný, ktorý patrí k najnovším objavom $\mathrm{v}$ tomto regióne s bohatou hudobnou históriou - sú to menzurálne fragmenty $\mathrm{z}$ väzby účtovnej knihy mesta Spišská Nová Ves z rokov 1514 - 1524. ${ }^{6}$ Druhým zaujímavým rukopisom sú Košické fragmenty (SK-BRu Inc. 318; ca 1465). Okrem piesne Prelustri elucencia Petra z Grudziądz sa v nich nachádza zná-

4 HACK, Achim Thomas: Ein anonymer Romzugsbericht von 1452 (Ps-Enenkel) mit den zugehörigen Personenlisten (Teilnehmerlisten, Ritterschlagslisten, Römische Einzugsordnung). In: Zeitschrift für deutsches Altertum und deutsche Literatur, 7. Stuttgart : Hirzel, 2007, s. 218-219.

5 STAEHELIN, Martin: Neues zu Werk und Leben von Petrus Wilhelmi: Fragmente des mittleren 15. Jahrhunderts mit Mensuralmusik im Nachlaß von Friedrich Ludwig. (= Kleinüberlieferung mehrstimmiger Musik vor 1550 in deutschem Sprachgebiet, 3). Göttingen : Vendenhoeck \& Ruprecht, 2001, s. 45.

6 PETŐCZOVÁ, Janka: Hudba ako kultúrny fenomén v dejinách Spiša. Raný novovek. Bratislava : Ústav hudobnej vedy SAV, Prešovský hudobný spolok Súzvuk, 2014, s. 132-136. 
me moteto Waltera Freya Ave regina celorum. Podobne ako Spišské fragmenty aj tieto pochádzajú z kláštora dominikánov v Košiciach.

Po dôkladnej charakteristike prameňov predkladá Paweł Gancarczyk v nasledujúcej kapitole Gatunki muzyczne analytický hudobnoteoretický pohlad na jednotlivé diela. Podrobne rozoberá problémy menzurálnej notácie, ktoré je nevyhnutné riešit ako prvé pri korektnej transkripcii a analýze hudby. Vychádza $\mathrm{z}$ traktátov, ktoré sa používali v čase štúdia skladatela v strednej Európe v prvej polovici 15. storočia. V prehladnej tabulke predstavuje v ôsmich traktátoch názvoslovie a definície stredovekých hudobných foriem. Nadväzuje pri tom na dlhoročné bádania Elżbiety Witkowskej-Zaremba, špecialistky na latinskú hudobnú terminológiu. ${ }^{7}$ Paweł Gancarczyk podrobne vysvetluje rozdiely medzi definíciami foriem, ktoré vykazovali vtedy vysokú variabilitu; v ich hierarchii však jednoznačne najvyššie stálo moteto (mutetus), premenlivé v počte hlasov, vztahov medzi nimi, v spôsobe ich textácie, technikou kánonu, resp. melodických, metrických a rytmických figúr. Ťažisko kapitoly predstavuje analýza hudobných foriem skladieb Petra z Grudziądz, ktoré sú rozdelené do troch skupín: piesne - cantiones, motetá a kánony $\mathrm{v}$ dvoch formách: rotulum a katschetum. Teoretické úvahy sú ilustrované notovými ukážkami z vlastných transkripcií autora knihy, ako aj z transkripcií Jaromíra Černého. ${ }^{8}$

Posledná, štvrtá kapitola - Tworczość je venovaná šiestim dielam Petra z Grudziądz; každé z nich je niečím zaujímavé. Pieseň Prelustri elucencia patrila v repertoári neskorého stredoveku $\mathrm{k}$ najpopulárnejším dielam (nachádza sa v dvadsiatich odpisoch, $\mathrm{v}$ pätnástich rukopisoch a v troch tlačiach); v Košických fragmentoch je jej najstarší zápis. Pieseň typu rondellus s názvom Prodigiis eximiis vznikla ako dielo $\mathrm{z}$ neskoršieho skladatelovho obdobia a použil v nej techniku fauxbourdon (nachádza sa len v jednom rukopise $\mathrm{v}$ Lipsku). V polytextovom motete Pneuma eucaristiarum je autorstvo skladatela spojené s hudbou i textom, a práve do tohto latinského textu zašifroval svoje meno. Izorytmické štvorhlasné moteto Probitate eminentem hodnotí autor knihy ako najvýznamnejšie dielo Petra z Grudziądz v kontexte hudby v strednej Európe a zároveň $\mathrm{v}$ celej európskej tradícii polyfonickej hudby. V texte sa opät skrýva akrostich, je teda autorsky nespochybnitelné. Moteto je komponované majstrovskou polyfonickou technikou pre štyri hlasy (discantus, contratenor altus, contratenor bassus a tenor), ktorá využíva tesné spojenie textu a hudby. Ďalšia štvorhlasná skladba - kánon Presulem ephebeatum je zachovaná vo viacerých kópiách, aj v Spišských fragmentoch (o. i. aj vo Viedni a Lübecku). Táto skladba je jednou $\mathrm{z}$ často interpretovaných; pod oslavným charakterom textu napísaného na počest’ sv. Martina sa skrývajú žartovné narážky na tradície zviazané s dňom sv. Martina, ked’ sa v čase jesenných prác konali rôzne oslavy úrody, medzi ktoré patrilo aj pečenie vykŕmených husí; v skladbe sa dokonca v melódii ozýva gáganie husí a text sa „točí" okolo hostiny - „vezmi, a zjedz svoju hus“ (nimm, iss deine Gans). O podobné zábavné slovné hračky či prekáračky nebola vo vtedajších piesňach núdza. Poslednou analyzovanou skladbou v tejto záverečnej kapitole je jediná liturgická skladba Petra z Grudziądz - Kyrie Fons bonitas -, ktorá bola súčastou ordinarium missae; jej základ tvorí chorálna melódia ako cantus firmus doplnená dvoma hlasmi - contratenorom a tenorom - a jej súčastou sú aj také nuansy ako trópované časti (dokonca trópus $\mathrm{v}$ trópe). Dôkladné hudobnoteoretické analýzy všetkých šiestich skladieb sú založené na porovnávaní s relevantnou hudbou Európy obdobia premien hudobného štýlu v druhej tretine 15. storočia. Autor knihy poukazuje na skutočnost', že hudba Petra

7 WITKOWSKA-ZAREMBA, Elżbieta: Traktaty muzyczne z rękopisu WaN BOZ 61. In: „Notae musicae artis“. Notacja muzyczna w źródłach polskich XI-XVI wieku. Ed. Elżbieta Witkowska-Zaremba. Kraków : Musica Iagellonica, 1999, s. 487-537. WITKOWSKA-ZAREMBA, Elżbieta: Ars organisandi around 1430 and its Terminology (= Quellen und Studien zur Musiktheorie des Mittelalters, 3). Ed. Michael Bernhard. München : Bayerische Akademie der Wissenschaften, 2001, s. 367-423.

8 ČERNÝ, Jaromír (ed.): Petrus Wilhelmi de Grudencz. Magister Cracoviensis. Opera Musica. Kraków : Polskie Wydawnictwo Muzyczne, 1993. 
z Grudziądz vykazuje vysokú melodickú invenčnost' a že z jej vnútornej štruktúry môžeme vyčítat originálnu identitu jej tvorcu - autor bol básnik a zároveň aj skladatel' (hudobník), išlo teda o spojenie jeho poetických a muzikálnych schopností, ktoré zjednocoval duchovný princíp založený na konzervatívnejších tradíciách motetového princípu obdobia ars nova, neraz zasadených do úsmevných súvislostí (technikou paródie).

Vysoká profesionalita spracovanej problematiky predstavuje autora publikácie ako špecialistu nielen na stredovekú a renesančnú hudbu, ale aj ako historika, kulturológa, latinčinára a hudobného teoretika, pre ktorého je dôležitá hlbková analýza skúmaného javu. V knihe zúročil predchádzajúce muzikologické skúsenosti v oblasti výskumu dejín starých hudobných tlačí a výskumu kultúrnych dejín strednej Európy ako špecifického hudobného regiónu. Profesor Paweł Gancarczyk pôsobí v súčasnosti ako vedúci Oddelenia muzikológie v Umenovednom ústave Polskej akadémie vied (Instytut Sztuki
$P A N)$ vo Varšave, prednáša doma aj v zahraničí a je nositelom viacerých ocenení za svoju prácu (Prof. Hieronim Feicht Prize, Varšava 2001; Prix des Muses - Prix de l'Histoire, Paríž 2016). Je autorom knihy Musica scripto. Kodeksy menzuralne II połowy XV wieku na wschodzie Europy Łacińskiej (Warszawa : Instytut Sztuki Polskiej Akademii Nauk, 2001). Bol jedným z lídrov európskeho projektu HERA (Humanities in the European Research Area) Sound Memories: The Musical Past in Late-Medieval and Early-Modern Europe (2016 - 2019). Od roku 2019 je hlavným riešitel'om projektu Music in the Teutonic Order State in Prussia: Sources, Repertoires, Contexts a od roku 2020 je členom vedeckej spoločnosti Academia Europaea. Profesionálnu upútavku na knihu - sprevádzanú hudbou a tiež slovom samotného autora - môžu nájsţ záujemcovia na webovom portáli (<https://www.youtube.com/ watch? $\mathrm{v}=\mathrm{Q} 4 \mathrm{mPY} 2 \mathrm{TKZDQ}>$ ).

https://doi.org/10.31577/musicoslov.2021.2.4 Janka Petöczová

\section{Janko Blaho: Záhorácké pjesňičky. Súborné vydanie}

Ed. Peter Michalovič. Bratislava : Hudobné centrum v spolupráci so Záhorským múzeom v Skalici, 2018, 816 s. ISBN 978-80-89427-33-8

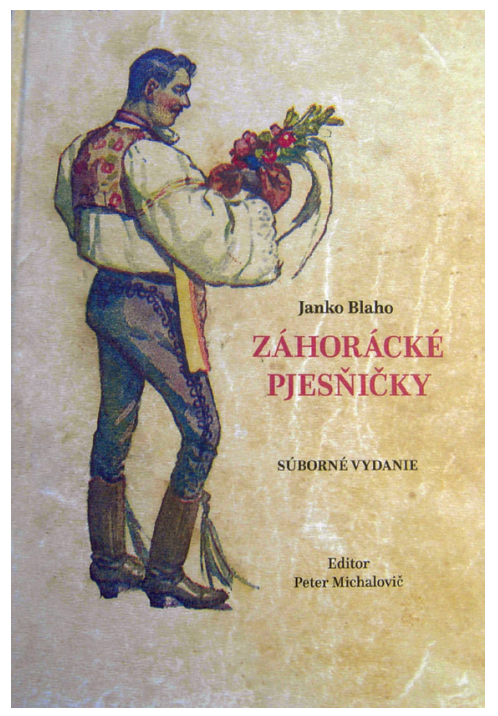

Dôležitou úlohou pri práci s historickými prameňmi ludových piesní je nielen ich uchovávanie v archívoch, múzeách a vedeckých inštitúciách, ale aj ich sprístupňovanie širšej verejnosti, editovanie, prípadne po čase aj nové vydanie. Najčastejšie ide o regionálne alebo lokálne piesňové zbierky, ktoré majú v praxi široké uplatnenie ako pramenno-kritické či popularizačné vydania. S týmto cielom pôvodne zbierali a vydávali svoje zápisy aj zberatelia - od profesionálnych bádatelov až po nadšencov, ktorí sa snažili najmä o zachytenie lokálneho repertoáru piesní $\mathrm{z}$ kraja, z ktorého pochádzali.

Z tohto dôvodu pôvodne vzniklo aj šest' dielov piesňovej zbierky zo zberatel'skej práce Janka Blaha (1901 - 1981), rodáka zo Skalice, jedného z prvých spevákov v opere Sloven- 